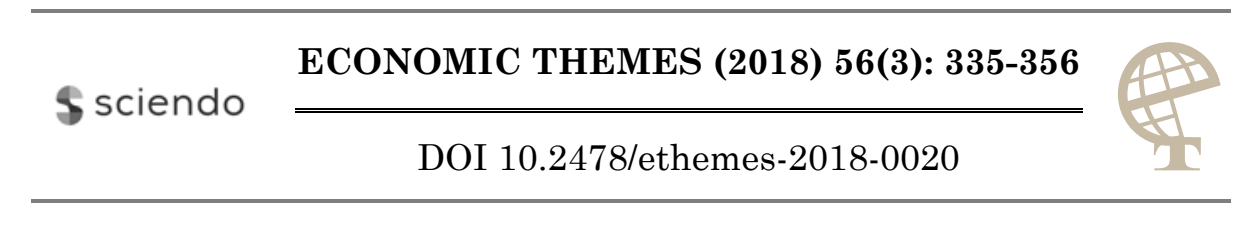

\title{
REGIONAL RETAIL SECTOR DEVELOPMENT IN SERBIA - KEY PERFORMANCE AND DEVELOPMENT INDICATORS' GAP
}

\section{Stojković Dragan}

Faculty of Economics University of Belgrade, Belgrade, Serbia

$\bowtie$ dstojkovic@ekof.bg.ac.rs

Manić Emilija

Faculty of Economics University of Belgrade, Belgrade, Serbia

$\bowtie$ geografija@ekof.bg.ac.rs

Bogetić Zoran

Faculty of Economics University of Belgrade, Belgrade, Serbia

$\bowtie$ bogeticz@ekof.bg.ac.rs

Dokić Aleksa

Faculty of Economics University of Belgrade, Belgrade, Serbia

$\bowtie$ dokic@ekof.bg.ac.rs

UDC

332.1:339.

37(497.11)

Original

scientific

paper

\begin{abstract}
Are there significant regional differences in regional retail development in Serbia? This was the main research question at the beginning of writing this paper. The main goal of this paper was to analyse regional differences in retail development based on existing statistical data. The idea was to point out regions with underdeveloped retailing and the one with endangered retail competition. Thorough desk research has been performed. It included both literature review and data collection from available official sources. Existing retail data have been analysed. However, the lack of data at lower levels of aggregation (regional and local) prevents the authors from getting strong conclusions. In addition, the lack of data also altered the main research question, which has now become adequacy of data in the retail sector and potential solutions for that problem. The noted lack of crucial data and solutions for solving this problem were the main purpose of this paper. The main finding is that decision makers in Serbia do not have adequate information about retail network. This is a problem because it is very hard to prove anticompetitive actions or to plan (stimulate) retail development without relevant data from both
\end{abstract}


government and business point of view. Retail census would help getting key indicators about development of retailing in certain regions and municipalities. However, the solution needs to be sustainable. Therefore, some legislative requirements should provide information for census update.

Received: Keywords: Retailing, Regional development, Information base, 13.04.2018 Accepted: 04.07.2018 Competition, Serbia, Retail network

JEL classification: L81, F12, R11

\section{Introduction}

Global society today is mostly founded on the postindustrial socioeconomic paradigms, so the mass consumption has become an integral and important part of everyday life. The economic structure of the most developed countries shows that the service sector prevails in their economic structure and that their economy depends greatly on the processes which occur within the service sector. Retailing is one of the services that is very specific because it reacts on the changes that is happening on both the supply and demand side.

Regional development of the retail sector is very important because it affects all the participants in the marketing channels. This implies both macro and micro economic consequences(Van Leeuwen, 2010). Retailers are always in focus. If something is wrong in the economy, it is easy to blame it on retailers because people are very sensitive when it comes to retailing. This is especially true when consumer choice is endangered.

Is regional retail development with geographical focus important in the era of the Internet? The answer is positive because the Internet and physical retail locations are complementary (Waldfogel, 2010). Combination of online and offline retailing is the winning strategy in the $21^{\text {st }}$ century. It cannot be forgotten that offline retailing will dominate the market in the years to come as well. Therefore, spatial retail development is very important. However, it should be pointed out that online retailing has regional dimensions as well. Websites are available globally, whereas the delivery is often limited to local or regional areas.

Different factors influence the retail sector - in spite the technological innovations, the location still matters, coupled with a lot of issues considering the preferences and models of the shopping habits (Altenburg, Kulke, HampelMilagrosa, Peterskovsky, \& Reeg, 2016). The analysis of consumer's characteristics, distribution and behaviour has become a huge part of the retail researches in the past few decades (Berman, 2012; Larson, Bradlow, \& Fader, 2005; Waxell, 2014). 
The retail industry is a complex, heterogeneous entity. Market volatility, different economic standards and economic development are just some of the factors with a strong influence on a regional differentiation of retail industry development.

Are there significant regional differences in regional retail development in Serbia? This was the main research question at the beginning of writing this paper. The main goal of this paper was to analyse regional differences in retail development based on existing statistical data. The idea was to point out regions with underdeveloped retailing and the one with endangered retail competition.

Within this research the authors have analysed existing retail data, as well as demographic factors that influence retailing. Existing retail data have been analysed. However, the lack of data at lower level of aggregation (regional and local) prevents the authors from getting strong conclusions. In addition, the lack of data also altered the main research question, which has now become adequacy of data in retail sector. The noted lack of crucial data and solutions for solving this problem were the main purpose of this paper.

\section{Demographical factors of retail development in Serbia}

In the context of overall internationalization of the retail space, the knowledge of the local culture consumption and consumers is one of the most important elements of the corporate strategic success (besides the logistics and distribution systems, IT systems and supply-chain management, knowledge and international management experience), (Wrigley \& Lowe, 2002). Because of that a great deal of researches within the retail sector analyse the market through the observation of prevailing factors which have shaped the retail market.

An analysis of the overall population together with all its characteristics (demographic structures and the household structures) provides the "big picture" of potential retail demand within a society. It provides the necessary information which enables the decision makers to calibrate the chosen retail strategy in order to minimise the risk and maximise the profit. There are a lot of researches on the influences of demographic factors on the retail development which concluded that household size, income level, education level and occupation are among the most important ones (Iqbal, Ghafoor, \& Shanbaz, 2013; Vanhonacker, Lengard, Hersleth, \& Verbeke, 2010). Today consumer society is influenced by different global processes such as mass production-mass consumption, ICT, higher mobility, as well as new and specific social processes. Albite, there are certain geographical specifics that differentiate one community from another, one culture from another, one market from another. Demographical and social analyses have tried to investigate all those disparities (age, gender, marital status and family size, education and household income), and to show their distribution over different spatial levels in order to identify consumers' shopping habits. 
Serbia is a middle-income economy with a much lower level of GDP per capita (PPP) then the EU-28 (according to the official statistics it is around 14.000 \$). It is relatively small market of some 7 million people, which characterise by the typical demographical and social processes for the peripheral regions (East and Southeastern Europe): depopulation, rural emigration, aging process, reducing the average household size and the family size.

The depopulation process is quite huge in Serbia (between two censuses in the period 2002-2011, Serbia has lost over 310.000 people). For all retailers, the total population size, its composition and distribution, represent crude measures of retail market size (Mlambo 2017). So, considering the national market size, it could be concluded that the retail market in Serbia has been shrinking over the years. The population growth components indicate that this process last for years and probably will continue in the future (the natural increase rate is negative for the whole national territory $(-5,1 \%)$ and it varies from $-5,4 \%$ in the region of Vojvodina, through $1,7 \%$ in the Belgrade region up to $-6,6 \%$ in Central Serbia). This natural increase trends will continue to affect the households' size as well as their structure further in the future. At the same time, they are important factors of the demographic structures as well, which is even more important for the retailer (who the consumers are, where they live, what they earn and how they spent their money).

Figure 1. The age structure and ageing index in Serbia, by regions (2016)

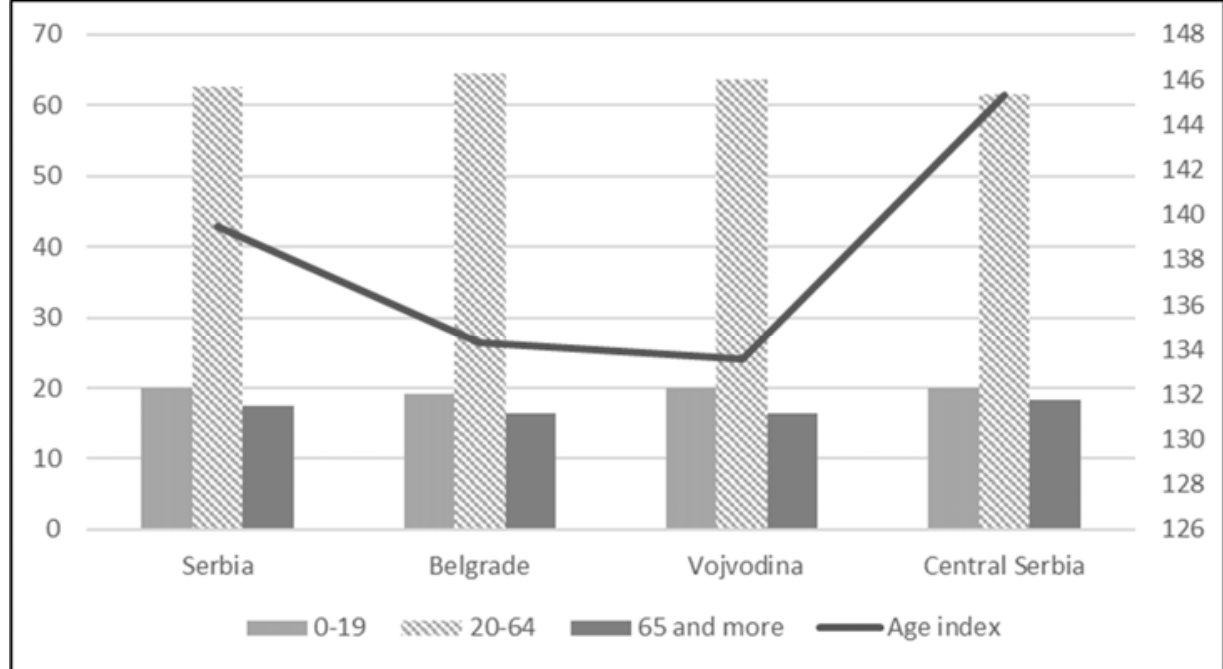

Source: SORS, authors' calculations

Age structure is a direct consequence of the growth trends within the population. It is an important indicator of the consumer behaviour because personal expenditures change as individuals grow older (children are interested in toy stores, 
elderly in pharmacies, young in night life), (White \& Gray, 1996). It is evident that older consumers are much more loyal to the store and they are lesser interesting in the new thing, innovations or updated information (Straughan \& Albers-Miller, 2001). In Serbia, the population age structure is unfavourable (ageing rate index for whole state is 139,5 and it varies through the regions: the highest is in Central Serbia, over 145). Such aging process (deep demographic age) results with certain age structure are shown in Figure 1. The highest share has the working contingent of the Serbian population (over $60 \%$ ), but, although, the young people share is higher than old, it is evident that the population group of 65 and more is increasing (close to one fifth of the whole population and the highest is in Central Serbia).

Another, maybe even more important indicator for the retail market analysis is the household income. It represents residents' spending power (retailer is especially interested in the average household income and minimum number of household with a certain income). Household income includes all revenues (incomes from different sources). The higher this income is, the more the consumers will buy, and more often. In comparison with the average household income in Serbia (57.028 RSD), only the Belgrade region has a higher income (70.804 RSD); all other regions are below the national average (Vojvodina region around 54.500 RSD and Central Serbia around 51.000 RSD). Also, the household income structure is as expected: the highest wages are in the Belgrade region (almost 1,5 times higher than national average), but the pensions are similar throughout all regions (Figure 2). However, the biggest geographical disparities are within the group 'other household incomes' (income from agriculture, hunting and fishing, external receipts, real estate related income, other social insurance receipts, donations and awards, other receipts).

Figure 2. Average household income and household size, by regions (2016)

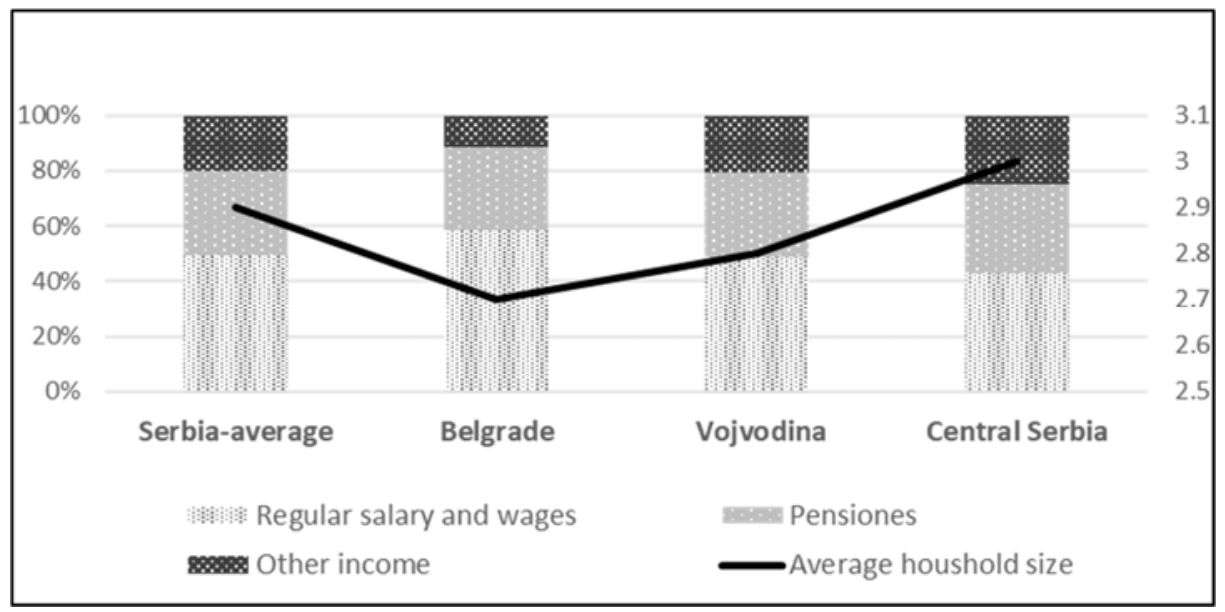

Source: National household budget survey 2015-2017, author's calculations 
The Central Serbia region shows greater share of those "other incomes" as well as Vojvodina. It could be explained by the fact that eastern part of Central Serbia has quite a significant portion of diaspora population, which regularly send money to their families (remittances), while Vojvodina's households, especially those out of urban areas usually have an extra income from agriculture. Knowing that consumption depends greatly on the size as well as the structure of the household, it is interesting to compare household income by these parameters. The smallest household are in Belgrade region where the highest incomes are present (an important information for the retailers of the specialized stores and more expensive goods). On the other hand, Central Serbia has households which are bigger than the national average.

Within the household analysis it is important to know its structure, and the stage within the family life cycle. Bigger families ought to spend more than single or two-member families (they shop more often, need broader assortment, often make stock of groceries, and are usually ready to shop in bigger stores than in small neighbouring ones) (Leszczyc, Sinha, \& Timmermans, 2000). The family structure in Serbia shows that the couples with children make up more than half of the total number of families (around 52\%). This is very similar throughout all the regions. However, the largest geographical variations are within other two groups of family types: couples without children and one-parent families. The highest share of one-parent family is in Belgrade region $(21,2 \%)$ and the smallest is in Central Serbia $(15,2 \%)$ which corresponds to the age structure of the regions. On the other side, the Belgrade region has the smallest share of couples without children (26.2\% comparing to the $32.9 \%$ in Central Serbia).

The findings of the single or SSWDs households (single, separated, widowed, divorced) geographical variations is even more interesting (Figure 3). This group of households is particularly important to the retailers because they represent a market niche which shows excellent shopping habits (Reddy \& Srinivas, 2015). Comparing these groups between themselves, it can be noted that in the Belgrade region the higher share is attributed to single women, rather than men (single women have higher share than married ones). In Central Serbia it is quite opposite, and in accordance to the expected traditional customs. Vojvodina is much closer to the Belgrade region in this sense. This indicator could be closely tied to the living standard and economic development, as well as to the educational level of the population.

Figure 3 also shows that the Belgrade region has the highest share of population with tertiary education (colleges and faculties). Comparing to other two regions, it is expected to be more similar to Vojvodina than Central Serbia where the share of high educated people is the lowest (below 12\%). Education, together with income and some other social aspects, produce certain social status, and that status shapes the consumer behaviour in the sense of the purchase preferences (Prasad \& Aryasri, 2011; Sinha \& Banerjee, 2004). Higher income generates 
higher social status which enables more opportunities for good education and, furthermore, good education creates possibilities for better occupation, and consequently higher income. It is evident that higher educated people buy more expensive goods, often in smaller, specialty retail stores located in their vicinity, whereas less educated people prefer shopping at discount retail outlets and chain stores.

Figure 3. Educational structure and marital status, by region (2016)

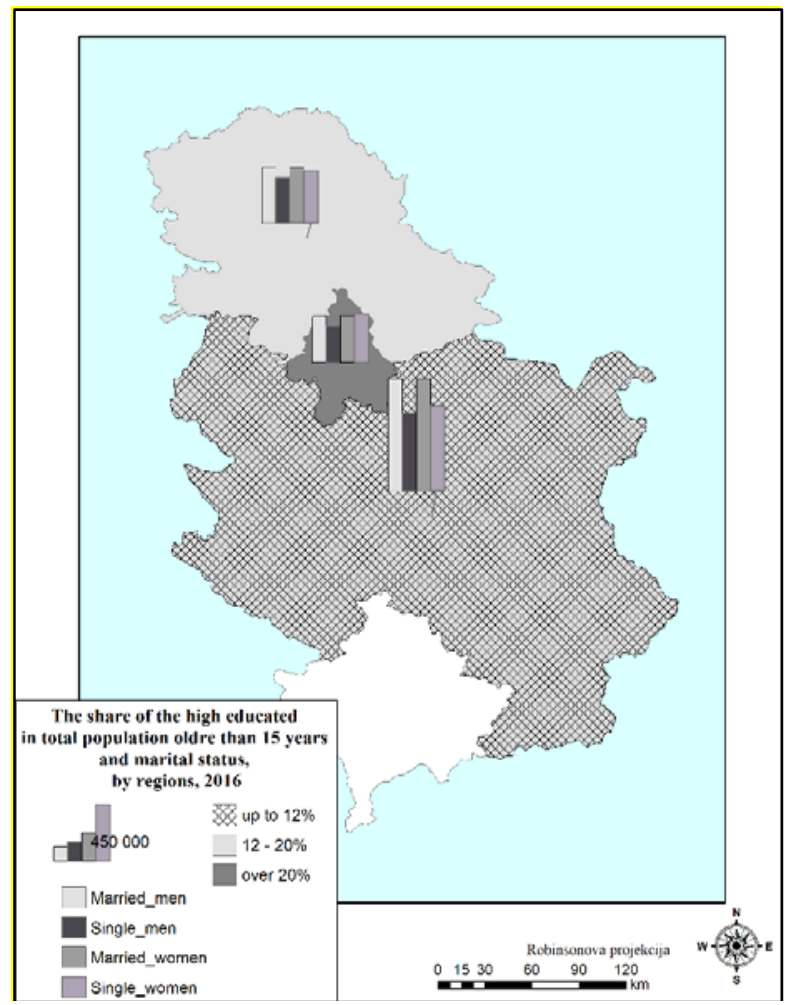

Source: SORS, authors' calculations

\section{Economic indicators of regional retail development in Serbia}

In order to track and analyse the dynamics of national and subnational (regional) changes within the retail industry in Serbia, available macroeconomic statistics were analysed. Analysis was aimed at determining whether any significant differences can be identified regarding regional development of retail sector in northern and southern part of Serbia. This regional division opted for was chosen because of the format of available statistical data, as well as accepted national 
division between "richer" north and "poorer" south. In order to attain relevant data, effort was made to decouple the impact of Belgrade region from the overall aggregated data of the northern region (further in the text - Vojvodina). For this purpose, data regarding turnover, number of employees, number of firms, and number of stores were analysed and further combined, producing synthetic parameters which complete a comprehensive macro perspective of the retail industry development in Serbia. Data gathered represent the entire national retail sector, excluding the retail of vehicles and motorcycles.

Structural regional retail development data related to annual turnover and number of employees, stores and firms are presented in Appendices A, B, C and D, respectively. When analysing annual turnovers in the retail industry in Serbia, a positive trend can be identified. Total turnover in 2016 has surpassed the level achieved in 2012, the following a three-year unfavourable situation. As far as regional dispersion goes, northern Serbia amounts to just under $65 \%{ }^{1}$ of total national sales generation capacity. It has to be taken into account that the region of Belgrade produces around $37 \%$ of the total national retail turnover. This implies that the region of Vojvodina generates only $26 \%{ }^{3}$ of total sales, compared to around $36 \%{ }^{4}$ originating from the southern part of the country. Overall ratios between aforementioned regions are relatively constant, whilst absolute values follow an upward trend. Revenue still represents one of the most important economic indicators of retail activity (Zhang et al., 2010). For this reason, annual turnover represents the basis for the majority of derived synthetic indicators.

Table 1. Depiction of retail industry's national and regional employment share

\begin{tabular}{|c|c|c|c|c|c|c|c||}
\hline \multicolumn{7}{|c|}{ Share of employment in retail industry (\% of total number of employees) } \\
\hline Year & $\begin{array}{c}\text { Serbia - } \\
\text { share }\end{array}$ & $\begin{array}{c}\text { Northern } \\
\text { Serbia - } \\
\text { share }\end{array}$ & $\begin{array}{c}\text { Southern } \\
\text { Serbia - } \\
\text { share }\end{array}$ & $\begin{array}{c}\text { Northern } \\
\text { Serbia - } \\
\text { share in } \\
\text { employment } \\
\text { in north }\end{array}$ & $\begin{array}{c}\text { Vojvodina - } \\
\text { share of } \\
\text { employment } \\
\text { in north }\end{array}$ & $\begin{array}{c}\text { Belgrade } \\
\text { region - } \\
\text { share of } \\
\text { employment } \\
\text { in north }\end{array}$ & $\begin{array}{c}\text { Southern } \\
\text { Serbia - } \\
\text { share in } \\
\text { employment } \\
\text { in south }\end{array}$ \\
\hline $\mathbf{2 0 1 4}$ & $7.134 \%$ & $3.484 \%$ & $3.650 \%$ & $6.896 \%$ & $3.462 \%$ & $1.734 \%$ & $7.377 \%$ \\
\hline $\mathbf{2 0 1 5}$ & $7.134 \%$ & $3.487 \%$ & $3.647 \%$ & $6.939 \%$ & $3.469 \%$ & $1.744 \%$ & $7.331 \%$ \\
\hline $\mathbf{2 0 1 6}$ & $6.699 \%$ & $3.263 \%$ & $3.436 \%$ & $6.494 \%$ & $3.203 \%$ & $1.654 \%$ & $6.906 \%$ \\
\hline \multicolumn{7}{|c|}{ Source: SORS, authors' calculations } \\
\hline
\end{tabular}

\footnotetext{
${ }^{1}$ Figure derived from Appendix A

${ }^{2}$ Figure derived from Appendix A

${ }^{3}$ Figure derived from Appendix A

${ }^{4}$ Figure derived from Appendix A
} 
Analysis depicted in Appendix B identified a negative trend regarding the number of employees in retail industry, which has fallen by $23 \%{ }^{5}$ in the $2012-2016$ period. Another important fact is that the decline is associated with the 2012-2014 period, whereas the figures have stagnated in the last few years. The sharp decline in the total workforce in retail industry can be mostly attributed to significant changes in the Belgrade region, where the analysed 5-year period saw the number of employees almost halved. One important finding is that southern Serbia employs more than half of the workforce in the retail industry. This drop in employment is significant from a national point of view, since the retail sector employs around $7 \%$ of employed labour force, as seen from Table 1.

When coupled with the total number of retail stores in Serbia, a synthetic indicator of the average number of employees per store can be derived. This is shown in Table 2.

Table 2. Synthetic indicator depicting the average number of employees per store

\begin{tabular}{||c|c|c|c|c|c||}
\hline \multicolumn{7}{|c||}{ Average number of employees per store } \\
\hline Year & $\begin{array}{c}\text { Serbia - } \\
\text { total }\end{array}$ & $\begin{array}{c}\text { Northern } \\
\text { Serbia - total }\end{array}$ & $\begin{array}{c}\text { Vojvodina - } \\
\text { total }\end{array}$ & $\begin{array}{c}\text { Belgrade } \\
\text { region - total }\end{array}$ & $\begin{array}{c}\text { Southern } \\
\text { Serbia - total }\end{array}$ \\
\hline $\mathbf{2 0 1 2}$ & 2.8 & 2.6 & 2.7 & 2.6 & 3.1 \\
\hline $\mathbf{2 0 1 3}$ & 2.9 & 2.6 & 2.7 & 2.6 & 3.3 \\
\hline $\mathbf{2 0 1 4}$ & 3.1 & 2.7 & 2.7 & 2.7 & 3.7 \\
\hline $\mathbf{2 0 1 5}$ & 3.2 & 2.8 & 2.8 & 2.8 & 3.8 \\
\hline
\end{tabular}

Source: SORS, authors' calculations

The depicted figures show rather balanced figures for Vojvodina and Belgrade, but much higher numbers for southern Serbia. These figures alone cannot be a solid basis for any decisive conclusion-deriving process but indicate somewhat inefficient operational business conduct compared to the situation in the northern region. Additional insight into identified competitive gap between northern and southern Serbia is gained when average turnover per employee indicator is calculated. Significant gap regarding this parameter is shown in Table 3, where on average an employee in a northern store generates almost double the revenue compared to its southern counterparts. These figures show a significant competitive disadvantage in terms of resource utilisation, operational optimisations and income generating.

Final indicators of regional retail activity are related to the number of firms and its corresponding stores, as seen in Appendices C and D. In terms of the number of retail stores, the Serbian market has experienced a significant drop, especially the region of Belgrade.

\footnotetext{
${ }^{5}$ Figure derived from Appendix B
} 
Table 3. Synthetic indicator depicting the average turnover per employee in the retail industry

\begin{tabular}{||c|c|c|c|c|c||}
\hline \multicolumn{5}{|c|}{ Average annual turnover per employee in retail industry (in mil. RSD) } \\
\hline Year & $\begin{array}{c}\text { Serbia - } \\
\text { total }\end{array}$ & $\begin{array}{c}\text { Northern } \\
\text { Serbia - } \\
\text { total }\end{array}$ & $\begin{array}{c}\text { Vojvodina - } \\
\text { total }\end{array}$ & $\begin{array}{c}\text { Belgrade } \\
\text { region - } \\
\text { total }\end{array}$ & $\begin{array}{c}\text { Southern } \\
\text { Serbia - } \\
\text { total }\end{array}$ \\
\hline $\mathbf{2 0 1 2}$ & 4.159 & 4.923 & 4.764 & 5.036 & 3.242 \\
\hline $\mathbf{2 0 1 3}$ & 4.525 & 5.863 & 4.502 & 7.355 & 3.203 \\
\hline $\mathbf{2 0 1 4}$ & 5.259 & 6.915 & 5.472 & 8.369 & 3.680 \\
\hline $\mathbf{2 0 1 5}$ & 5.313 & 6.890 & 5.594 & 8.186 & 3.806 \\
\hline $\mathbf{2 0 1 6}$ & 5.765 & 7.505 & 6.377 & 8.603 & 4.112 \\
\hline
\end{tabular}

Source: SORS, authors' calculations

Table 4. Synthetic indicator depicting the average number of stores per firm in retail industry

\begin{tabular}{||c|c|c|c||}
\hline \multicolumn{4}{|c|}{ Average number of stores per firm in retail industry } \\
\hline Year & Serbia - total & $\begin{array}{c}\text { Northern Serbia - } \\
\text { total }\end{array}$ & $\begin{array}{c}\text { Southern Serbia - } \\
\text { total }\end{array}$ \\
\hline $\mathbf{2 0 1 2}$ & 13.2 & 11.9 & 15.5 \\
\hline $\mathbf{2 0 1 3}$ & 10.2 & 8.6 & 13.1 \\
\hline $\mathbf{2 0 1 4}$ & 8.4 & 7.2 & 10.5 \\
\hline $\mathbf{2 0 1 5}$ & 8.2 & 7.1 & 10.3 \\
\hline
\end{tabular}

Source: SORS, authors' calculations

On the contrary, Appendix D shows that the number of retail companies have had an upward trend, except in 2016. Southern Serbia amounts to around $34 \%{ }^{6}$ of all registered retail firms, but envelopes $43.5 \%{ }^{7}$ of the total number of stores. These facts indicate comparatively higher level of market concentration in the south confirmed by a synthetic indictor depicting an average number of stores per firm in retail industry derived in Table 4 . Numbers show that southern region supports a much higher number of stores per company than the northern region, whereas both parameters are facing a significant negative trend. Connected to this consideration is the analysis of average turnover per store, shown in Table 5. Although the national market possesses a positive trend, a gap in average revenue generated per store between northern and southern regions is apparent. Stores in southern Serbia are generating less revenue, especially compared to the Belgrade region. This fact is not quite intuitive, since higher market concentration levels established earlier should lead to a higher revenue generating capacity. Relative operational inefficiencies mentioned earlier can be pointed out as potential causes for this discrepancy.

${ }^{6}$ Figure derived from Appendix D

${ }^{7}$ Figure derived from Appendix C 
Stojković et al. / Economic Themes, 56(3): 335-356

Table 5. Synthetic indicator depicting the average turnover per store in the retail industry

\begin{tabular}{||c|c|c|c|c|c||}
\hline \multicolumn{6}{|c|}{ Average turnover per store in retail industry (in mil. RSD) } \\
\hline Year & $\begin{array}{c}\text { Serbia - } \\
\text { total }\end{array}$ & $\begin{array}{c}\text { Northern } \\
\text { Serbia - } \\
\text { total }\end{array}$ & $\begin{array}{c}\text { Vojvodina - } \\
\text { total }\end{array}$ & $\begin{array}{c}\text { Belgrade } \\
\text { region - } \\
\text { total }\end{array}$ & $\begin{array}{c}\text { Southern } \\
\text { Serbia - } \\
\text { total }\end{array}$ \\
\hline $\mathbf{2 0 1 2}$ & 11.725 & 13.032 & 12.890 & 13.128 & 9.915 \\
\hline $\mathbf{2 0 1 3}$ & 13.174 & 15.274 & 11.954 & 18.777 & 10.550 \\
\hline $\mathbf{2 0 1 4}$ & 16.342 & 18.556 & 14.633 & 22.542 & 13.462 \\
\hline $\mathbf{2 0 1 5}$ & 17.133 & 19.063 & 15.398 & 22.766 & 14.577 \\
\hline $\mathbf{2 0 1 6}$ & 18.696 & 20.984 & 17.617 & 24.339 & 15.723 \\
\hline
\end{tabular}

Source: SORS, authors' calculations

Final considerations within this section are aimed at providing a benchmark analysis, in order to determine the relative position of Serbia, compared to the countries of EU-28 (Table 6).

Table 6. Comparison between Serbia and EE-28 countries in terms of retail turnover per capita

\begin{tabular}{|c|c|c|c|c|c|c|c|c|c|}
\hline Country & $\begin{array}{c}\text { Total } \\
\text { retail } \\
\text { turnover } \\
(2010, \text { in } \\
\text { mil. } \\
\text { Euros) }\end{array}$ & $\begin{array}{c}\text { Total } \\
\text { population } \\
(\mathbf{2 0 1 0 )}\end{array}$ & $\begin{array}{c}\text { Retail } \\
\text { turnover } \\
\text { per } \\
\text { capita } \\
(2010, \\
\text { Euros) }\end{array}$ & 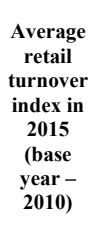 & $\begin{array}{c}\text { Total } \\
\text { retail } \\
\text { turnover } \\
(2015, \text { in } \\
\text { mil. } \\
\text { Euros) }\end{array}$ & $\begin{array}{c}\text { Total } \\
\text { population } \\
(\mathbf{2 0 1 5})\end{array}$ & $\begin{array}{c}\text { Retail } \\
\text { turnover } \\
\text { per } \\
\text { capita } \\
(2015, \\
\text { Euros) }\end{array}$ & $\begin{array}{c}\text { Relative } \\
\text { change } \\
\text { in retail } \\
\text { turnover } \\
\text { per } \\
\text { capita } \\
(2010- \\
2015 \text {, in } \\
\%)\end{array}$ & 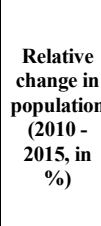 \\
\hline EY-28 * & $2,592,034.0$ & $498,931,998.0$ & $5,195.2$ & 107.2 & $2,778,660.4$ & $508,401,408.0$ & $5,465.5$ & 5.20 & 1.90 \\
\hline Belgium & $83,438.0$ & $10,839,905.0$ & $7,697.3$ & 111.1 & $92,699.6$ & $11,208,986.0$ & $8,270.1$ & 7.44 & 3.40 \\
\hline Bulgaria & $9,668.9$ & $7,421,766.0$ & $1,302.8$ & 140.5 & $13,584.8$ & $7,202,198.0$ & $1,886.2$ & 44.78 & -2.96 \\
\hline $\begin{array}{c}\text { Czech } \\
\text { Republic }\end{array}$ & $35,515.9$ & $10,462,088.0$ & $3,394.7$ & 109.7 & $38,960.9$ & $10,538,275.0$ & $3,697.1$ & 8.91 & 0.73 \\
\hline Denmark & $40,413.2$ & $5,534,738.0$ & $7,301.7$ & 100.3 & $40,534.4$ & $5,659,715.0$ & $7,161.9$ & -1.91 & 2.26 \\
\hline Germany & $474,357.7$ & $81,802,257.0$ & $5,798.8$ & 112.2 & $532,229.3$ & $81,197,537.0$ & $6,554.7$ & 13.04 & -0.74 \\
\hline Estonia & $4,538.7$ & $1,333,290.0$ & $3,404.1$ & 138.3 & $6,277.0$ & $1,313,271.0$ & $4,779.7$ & 40.41 & -1.50 \\
\hline Ireland & $33,264.1$ & $4,549,428.0$ & $7,311.7$ & 102.5 & $34,095.7$ & $4,628,949.0$ & $7,365.8$ & 0.74 & 1.75 \\
\hline Greece & : & $11,183,516.0$ & : & 72.6 & : & $10,858,018.0$ & : & : & -2.91 \\
\hline Spain & $221,383.0$ & $46,486,619.0$ & $4,762.3$ & 91.6 & $202,786.8$ & $46,449,565.0$ & $4,365.7$ & -8.33 & -0.08 \\
\hline France & $419,291.0$ & $64,658,856.0$ & $6,484.7$ & 110.3 & $462,478.0$ & $66,415,161.0$ & $6,963.4$ & 7.38 & 2.72 \\
\hline
\end{tabular}




\begin{tabular}{|c|c|c|c|c|c|c|c|c|c|}
\hline Italy & $312,599.3$ & $59,190,143.0$ & $5,281.3$ & 100.6 & $314,474.9$ & $60,795,612.0$ & $5,172.7$ & -2.06 & 2.71 \\
\hline Cyprus & $5,561.7$ & $819,140.0$ & $6,789.7$ & 88.8 & $4,938.8$ & $847,008.0$ & $5,830.9$ & -14.12 & 3.40 \\
\hline Latvia & $5,444.2$ & $2,120,504.0$ & $2,567.4$ & 128.3 & $6,984.9$ & $1,986,096.0$ & $3,516.9$ & 36.98 & -6.34 \\
\hline Lithuania & $7,319.1$ & $3,141,976.0$ & $2,329.5$ & 135.8 & $9,939.3$ & $2,921,262.0$ & $3,402.4$ & 46.06 & -7.02 \\
\hline Luxembourg & $16,389.1$ & $502,066.0$ & $32,643.3$ & 135.1 & $22,141.7$ & $562,958.0$ & $39,331.0$ & 20.49 & 12.13 \\
\hline Hungary & $24,675.4$ & $10,014,324.0$ & $2,464.0$ & 124.1 & $30,622.2$ & $9,855,571.0$ & $3,107.1$ & 26.10 & -1.59 \\
\hline Malta & : & $414,027.0$ & : & 120.0 & : & $429,344.0$ & : & : & 3.70 \\
\hline Netherlands & $100,357.6$ & $16,574,989.0$ & $6,054.8$ & 98.0 & $98,350.4$ & $16,900,726.0$ & $5,819.3$ & -3.89 & 1.97 \\
\hline Austria & $54,907.7$ & $8,351,643.0$ & $6,574.5$ & 109.0 & $59,849.4$ & $8,576,261.0$ & $6,978.5$ & 6.14 & 2.69 \\
\hline Poland & $96,668.7$ & $38,022,869.0$ & $2,542.4$ & 114.7 & $110,879.0$ & $38,005,614.0$ & $2,917.4$ & 14.75 & -0.05 \\
\hline Portugal & $47,211.2$ & $10,573,479.0$ & $4,465.1$ & 85.9 & $40,554.4$ & $10,374,822.0$ & $3,908.9$ & -12.46 & -1.88 \\
\hline Romania & $27,292.5$ & $20,294,683.0$ & $1,344.8$ & 132.2 & $36,080.7$ & $19,870,647.0$ & $1,815.8$ & 35.02 & -2.09 \\
\hline Slovenia & $11,199.5$ & $2,046,976.0$ & $5,471.2$ & 103.5 & $11,591.5$ & $2,062,874.0$ & $5,619.1$ & 2.70 & 0.78 \\
\hline Slovakia & $16,209.3$ & $5,390,410.0$ & $3,007.1$ & 110.7 & $17,943.7$ & $5,421,349.0$ & $3,309.8$ & 10.07 & 0.57 \\
\hline Finland & $35,511.3$ & $5,351,427.0$ & $6,635.9$ & 107.7 & $38,245.7$ & $5,471,753.0$ & $6,989.7$ & 5.33 & 2.25 \\
\hline Sweden & $63,396.3$ & $9,340,682.0$ & $6,787.1$ & 114.7 & $72,715.6$ & $9,747,355.0$ & $7,460.0$ & 9.91 & 4.35 \\
\hline $\begin{array}{c}\text { Great } \\
\text { Britain }\end{array}$ & $385,883.7$ & $62,510,197.0$ & $6,173.1$ & 112.7 & $434,890.9$ & $64,875,165.0$ & $6,703.5$ & 8.59 & 3.78 \\
\hline Norway & $50,796.3$ & $4,858,199.0$ & $10,455.8$ & 116.4 & $59,126.9$ & $5,166,493.0$ & $11,444.3$ & 9.45 & 6.35 \\
\hline Croatia & $11,844.9$ & $4,302,847.0$ & $2,752.8$ & 106.6 & $12,626.7$ & $4,225,316.0$ & $2,988.3$ & 8.55 & -1.80 \\
\hline Serbia & $11,651.2^{* *}$ & $7,306,677 * *$ & $1,594.6$ & 100.8 & $11,744.4$ & $7,106,862 * *$ & 1652.5 & 3.63 & -2.73 \\
\hline
\end{tabular}

Source: Eurostat, National Department for Statistics

*EU-28 projection - only indices for 2015 are available, whereas the base indicator for 2010 is for EU-27

**Data for Serbia are imported from SORS

For this purpose, main comparison point was retail turnover per capita parameter, whereas the overall retail turnover and total population dynamics are provided to decompose two main indicator influencing factors. Unfortunately, the table shows that Serbia holds a very unfavourable position in this sense, since only Romania and Bulgaria have lower per capita values. This fact is even more concerning having in mind that all three countries have a significant depopulation trend. 


\section{Discussion}

Based on data available from the official statistics the authors could not properly answer on the research question about existence of the significant regional differences in regional retail development in Serbia. Although regional differences are obvious it is not possible to adequately quantify it. The lack of data also altered the main research question, which has now become adequacy of data in retail sector and potential solutions for that problem.

Previous analysis has shown that there are no adequate data about some key retailing development indicators in Serbia. This is the answer on newly formed research question concerning adequacy of retail data. Data about consumers are available at higher levels of disaggregation but the data about retail network are highly aggregated, and sometimes questionable in their estimative values. However, without relevant key retail network development indicators these data are not as useful as they could be.

Some data are available on a national level such as number of stores, retail turnover, number of employees in retailing, etc. These data are valuable. However, all these data are aggregated data and often estimations rather than precise data. Certain data are available on a national and regional level. However, regions are very wide: Serbia's North (Vojvodina and Belgrade) and Serbia's South (whole Central Serbia). In this instance, the level of aggregation is so high that it is not possible to get any valid conclusions. For example, the Belgrade region includes the whole territory of the City of Belgrade (all 17 municipalities with its urban and rural settlements). It is a well-known fact that retailing in New Belgrade municipality is very well developed with modern hypermarkets, supermarkets, shopping malls etc. However, retailing in Sopot and Barajevo, also the municipalities of Belgrade, is not on an equivalent development level.

There is much more differentiation in the region of southern Serbia. Retail development in Niš and Kragujevac is at a much higher level than in Priboj and Negotin. However, data aggregation does not allow us to confirm these findings. Retailing in some cities and municipalities is at much higher level because of a strong local retailers' presence (such as Proleter Metalac in Gornji Milanovac).

In Vojvodina, Novi Sad has the most developed retailing network, compared to the rest of the region. There are significant local and regional players which originate from smaller cities (towns) in Vojvodina such as Zrenanjin, Senta, Bačka Palanka, Nova Pazova (Gomex, BB trade, Podunavlje, SentaPromet etc.) Some of these retailers have more than 100 stores. National retailers are present in Vojvodina as well. However, there is a lack of modern retail formats in smaller settlements.

Additionally, there is no data available to draw precise conclusions. This is especially important for municipalities where retailing is underdeveloped, or where 
competitive market irregularities are present. The consequences of undeveloped retailing are numerous, and the main ones are:

1. Higher prices of goods. Lack of competitions and inefficiency of small independent retailers are the main factors;

2. Local customers cannot find adequate assortment in the stores. They often have to travel to bigger cities;

3. Suppliers do not have easy access to population in these areas.

It is very important to have data on a regional and local (level of municipality) in order to aid and guide the development of the retail sector. Decision makers at national and local level need adequate retail data at lower level of aggregation.

Also, it is important to know the level of competition in the Serbian retail sector. However, it is more important to know the level of competition on local retail markets. This is especially important for fast moving consumer goods retailing. In order to have a clear picture about competition level, decision makers need adequate data.The most important data (key indicators) are those that define retail offer in some local market, such as:

1. Total retail space in the local market and retail space by type of retailing (food, non-food, specialised, general etc.) according to official classification of retail formats('Pravilnik o klasifikaciji trgovinskih formata', 2014);

2. Number of stores;

3. Number of companies that operate retail stores in certain local market;

4. Derived data such as retail space per habitant, number of habitants per store, retail turnover per habitant etc.

In addition, georeferenced retail stores could be very useful in analysing retail situation in local markets. That would be enabled through using geographical information system (GIS) in retail decision making.

The main information that Serbia lacks is that about retail space. Some researchers have provided estimates of retail space as such. However, these were just analyses based on the sample and it was not entirely precise.

In order to get reliable retail data, Serbia needs retail census. Retail census seems like a large project, and it rightfully is. However, census would provide necessary information base that could improve government bodies and Commission for protection of competition decision making potential. In addition, census would just be a starting point. Legislation should include the retailer's obligation to report any store opening and closing, with following data. This would provide relevant data for updating retail information system. 


\section{Conclusion}

It was not possible to answer the research question concerning regional retail development in Serbia. Although official statistics provide data about retailing it is not sufficient. Level of aggregation is very high. Decision makers in Serbia do not have the adequate information about retail network. There is a lack of data on a regional and local level. This is a problem because it is very hard to prove anticompetitive actions or to plan (stimulate) retail development without relevant data from both government and business point of view.

Retail census would be a vital mean of acquiring key indicators about development of retail sector in certain regions and municipalities. However, the solution needs to be sustainable. Therefore, some legislative follow-up requirements should provide information for census update.

Key indicators of retail network development would enable decision makers on all decision-making levels to prevent negative trends in retail development and to protect and sustain market competition. In addition, these data would make urban planning easier and more precise, as well as enable stimulation plans for retail network development.

\section{References}

Altenburg, T., Kulke, E., Hampel-Milagrosa, A., Peterskovsky, L., \& Reeg, C. (2016). Making retail modernisation in developing countries inclusive: a development policy perspective. Bonn: Deutsches Institut für Entwicklungspolitik.

Berman, B. R. (2012). Retail Management: A Strategic Approach (12 edition). Boston: Pearson.

Iqbal, H. K., Ghafoor, M. M., \& Shanbaz, S. (2013). Impact of Demographic Factors on Store Selection: An Insight in Pakistani Society. Journal of Marketing Management, 1(1), 34-45.

Larson, J. S., Bradlow, E. T., \& Fader, P. S. (2005). An exploratory look at supermarket shopping paths. International Journal of Research in Marketing, 22(4), 395-414. https://doi.org/10.1016/j.ijresmar.2005.09.005

Leszczyc, P. T. L. P., Sinha, A., \& Timmermans, H. J. P. (2000). Consumer store choice dynamics: an analysis of the competitive market structure for grocery stores. Journal of Retailing, 76(3), 323-345. https://doi.org/10.1016/S00224359(00)00033-6

Lovreta, S., Stojković, D. "Informacioni sistem trgovine Republike Srbije", Ministarstvo trgovine i usluga i Republički zavod za statistiku, Beograd, 2010. ISBN 978-866161-000-4, COBISS.SR-ID 179039500

Prasad, C. J., \& Aryasri, A. R. (2011). Effect of shopper attributes on retail format choice behaviour for food and grocery retailing in India. International Journal of Retail \& Distribution Management, 39(1), 68-86. https://doi.org/10.1108/09590551111104486

Pravilnik o klasifikaciji trgovinskih formata. (2014, May 26). Vlada Republike Srbije, Ministarstvo poljoprivrede, trgovine, šumarstva i vodoprivrede, "Službeni glasnik" 
RS br. 47/2011 Retrieved 12 April 2018, from http://www.overa.rs/pravilnik-oklasifikaciji-trgovinskih-formata.html

Reddy, N. H., \& Srinivas, A. (2015). Impact of Demographic Factors of Indian Consumers on Online Shopping Behaviour. International Journal of Accounting and Business Management, 3(1), 310-317. https://doi.org/10.24924/ijabm/2015.04/v3.iss1/310.317

Sinha, P. K., \& Banerjee, A. (2004). Store choice behaviour in an evolving market. International Journal of Retail \& Distribution Management, 32(10), 482-494. https://doi.org/10.1108/09590550410558626

Straughan, R. D., \& Albers-Miller, N. D. (2001). An international investigation of cultural and demographic effects on domestic retail loyalty. International Marketing Review, 18(5), 521-541. https://doi.org/10.1108/EUM0000000006044

Van Leeuwen, E. S. (2010). The effects of future retail developments on the local economy: Combining micro and macro approaches: Combining micro and macro approaches. Papers in Regional Science, 89(4), 691-710. https://doi.org/10.1111/j.1435-5957.2010.00307.x

Vanhonacker, F., Lengard, V., Hersleth, M., \& Verbeke, W. (2010). Profiling European traditional food consumers. British Food Journal, 112(8), 871-886. https://doi.org/10.1108/00070701011067479

Waldfogel, J. (2010). Who Benefits Whom in the Neighborhood? Demographics and Retail Product Geography. Agglomeration Economics, 181-209.

Waxell, A. (2014). Geography and the retail industry: A literature review with a special focus on Sweden. Retrieved from http://urn.kb.se/resolve?urn=urn:nbn:se:uu:diva214074

White, J. R., \& Gray, K. D. (1996). Shopping centers and other retail properties: investment, development, financing, and management. John Wiley \& Sons.

Wrigley, N., \& Lowe, M. S. (2002). Reading retail: a geographical perspective on retailing and consumption spaces. Arnold. Retrieved from https://eprints.soton.ac.uk/15253/

Zhang, J., Farris, P. W., Irvin, J. W., Kushwaha, T., Steenburgh, T. J., \& Weitz, B. A. (2010). Crafting Integrated Multichannel Retailing Strategies. Journal of Interactive Marketing, 24(2), 168-180.

https://doi.org/10.1016/j.intmar.2010.02.002 


\section{Annex}

Appendix A. National and regional data regarding the number of employees in retail industry

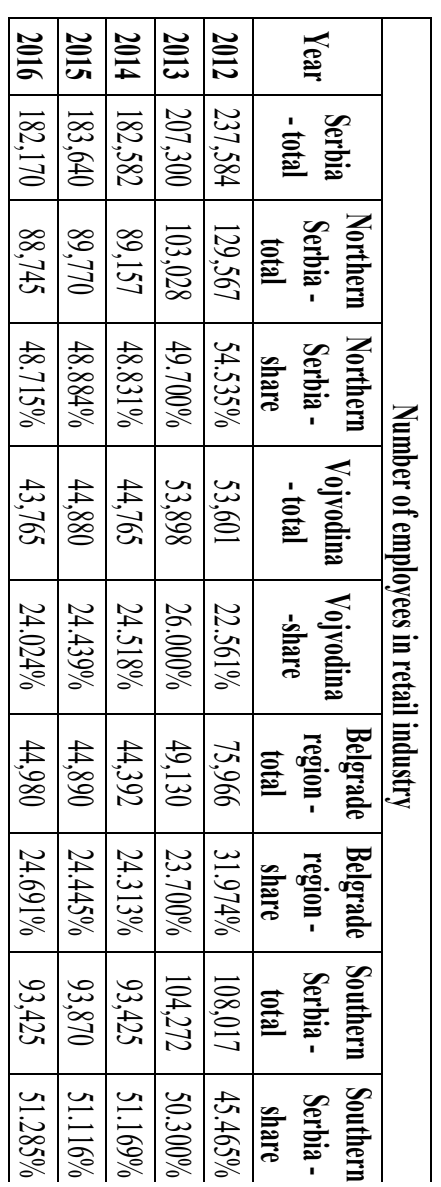

Source: National Department for Statistics - Annual statistics report 
Appendix B. National and regional data regarding total turnover in the retail industry

\begin{tabular}{|c|c|c|c|c|c|c|}
\hline$\stackrel{\tilde{\rho}}{\sigma}$ & 苍 & $\underset{\oplus}{\stackrel{\sigma}{\sigma}}$ & $\underset{\omega}{\tilde{\rho}}$ & $\stackrel{\widetilde{\rho}}{\sim}$ & 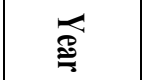 & \\
\hline 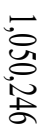 & 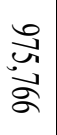 & 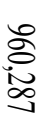 & 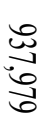 & $\begin{array}{l}\infty \\
\infty \\
\infty \\
.0\end{array}$ & 离兽. & \\
\hline 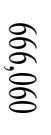 & 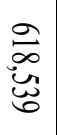 & $\begin{array}{l}\stackrel{a}{a} \\
\stackrel{ \pm}{ \pm}\end{array}$ & $\begin{array}{l}8 \\
\text { \&े } \\
\text { 8 }\end{array}$ & 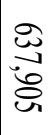 & (를 & \\
\hline $\begin{array}{l}\text { D } \\
\pm \\
0 \\
0\end{array}$ & 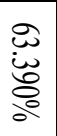 & 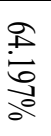 & 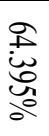 & $\begin{array}{l}\frac{9}{ \pm} \\
\text { un } \\
\text { a }\end{array}$ & 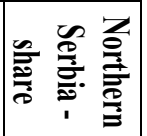 & $\underset{\equiv}{\equiv}$ \\
\hline 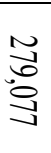 & $\begin{array}{l}\stackrel{N}{0} \\
\stackrel{0}{\circ}\end{array}$ & 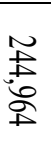 & 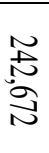 & $\begin{array}{l}\text { 岕 } \\
\text { 趸 } \\
\end{array}$ & 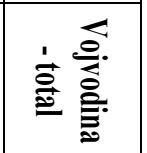 & 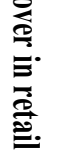 \\
\hline $\begin{array}{l}\tilde{a} \\
\text { wू } \\
\text { wू }\end{array}$ & 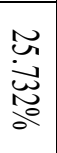 & 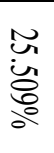 & 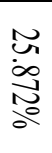 & $\begin{array}{l}\text { U. } \\
\infty \\
\frac{1}{0} \\
0\end{array}$ & 高㐫. & 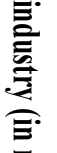 \\
\hline 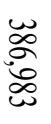 & $\begin{array}{l}\text { ज्ञ } \\
\text { 苟 }\end{array}$ & 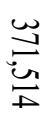 & 岕 & 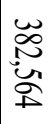 & 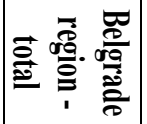 & $\begin{array}{l}\text { E. } \\
\text { 氙 }\end{array}$ \\
\hline $\begin{array}{l}w \\
\infty \\
\infty \\
\frac{a}{0}\end{array}$ & 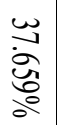 & $\begin{array}{l}w \\
\infty \\
\infty \\
\infty \\
0 \\
0\end{array}$ & 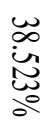 & 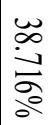 & 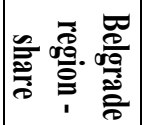 & \\
\hline $\begin{array}{l}\underset{\infty}{\infty} \\
\stackrel{ \pm}{\infty} \\
\sigma\end{array}$ & $\begin{array}{l}\stackrel{u}{\Delta} \\
\text { 売 }\end{array}$ & 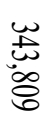 & $\begin{array}{l}\underset{\omega}{\omega} \\
\text { 岕 }\end{array}$ & 岕 & 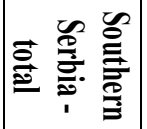 & \\
\hline 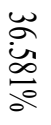 & $\begin{array}{l}\omega \\
\hat{\sigma} \\
\frac{a}{2}\end{array}$ & $\begin{array}{l}w \\
u \\
\infty \\
0 \\
0 \\
0\end{array}$ & 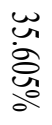 & 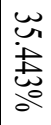 & 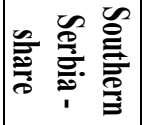 & \\
\hline
\end{tabular}

Source: National Department for Statistics - Annual statistics report 
Appendix C. National and regional data regarding the total number of stores in retail industry

\begin{tabular}{|c|c|c|c|c|c|c|}
\hline$\stackrel{\vec{g}}{a}$ & 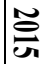 & $\stackrel{\vec{\theta}}{\oplus}$ & 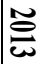 & 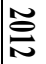 & 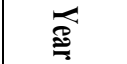 & \\
\hline 艺 & 朵 & 岕 & $\underset{1}{0}$ & $\frac{\infty}{N}$ & 宰 & \\
\hline$\stackrel{\omega}{ \pm}$ & 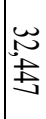 & w & 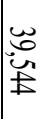 & $\begin{array}{l}\infty \\
\infty \\
0 \\
0\end{array}$ & 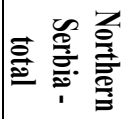 & \\
\hline 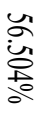 & 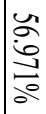 & 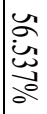 & un & 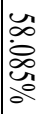 & 至 & \\
\hline $\begin{array}{l}\overrightarrow{1} \\
\infty \\
\pm\end{array}$ & 可 & $\begin{array}{l}-\bar{a} \\
\pm\end{array}$ & $\begin{array}{l}0 \\
0 \\
0 \\
8\end{array}$ & $\begin{array}{l}\sigma \\
\infty \\
\infty \\
0\end{array}$ & 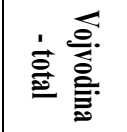 & 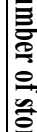 \\
\hline 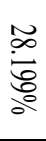 & $\begin{array}{l}\infty \\
\infty \\
0 \\
0 \\
0\end{array}$ & $\begin{array}{l}\infty \\
\infty \\
0 \\
0 \\
0 \\
0\end{array}$ & 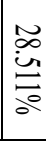 & 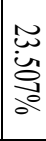 & 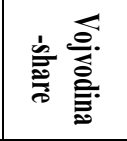 & 㤩 \\
\hline चु & 市 & $\begin{array}{l}0 \\
\frac{1}{0}\end{array}$ & $\begin{array}{l}\sigma 0 \\
N \\
N \\
+1\end{array}$ & 苞 & 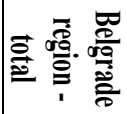 & 言 \\
\hline $\begin{array}{l}\infty \\
\infty \\
\frac{1}{0} \\
\frac{0}{0}\end{array}$ & $\begin{array}{l}\infty \\
\infty \\
0 \\
0 \\
0\end{array}$ & $\frac{\infty}{\infty}$ & $\begin{array}{l}\text { N } \\
\text { N } \\
\infty \\
0\end{array}$ & 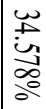 & 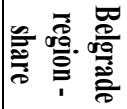 & \\
\hline 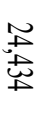 & N & 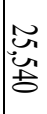 & 光 & w & 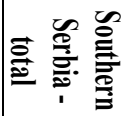 & \\
\hline $\begin{array}{l} \pm \\
\vdots \\
\text { के } \\
\text { â }\end{array}$ & 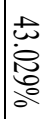 & 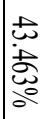 & $\begin{array}{l}\frac{1}{1} \\
\frac{1}{a} \\
\frac{a}{0}\end{array}$ & $\begin{array}{l} \pm \\
\underset{0}{0} \\
\vdots \\
0\end{array}$ & 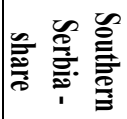 & \\
\hline
\end{tabular}

Source: National Department for Statistics - Annual statistics report 
Appendix D. National and regional data regarding the number of firms in the retail industry

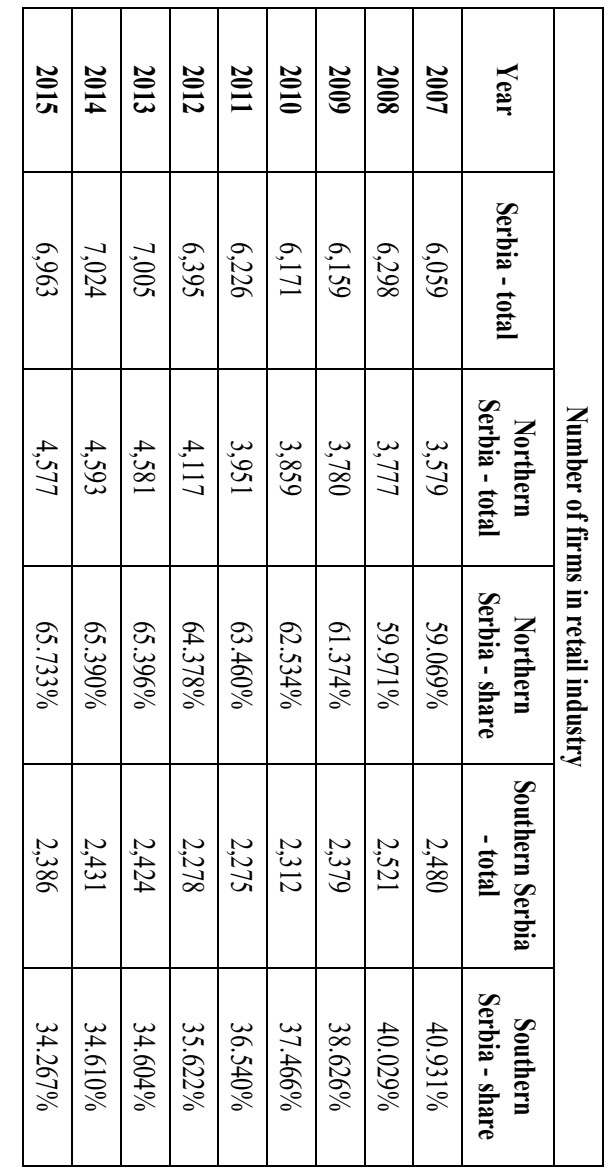

Source: National Department for Statistics - Annual statistics report 
Stojković et al. / Economic Themes, 56(3): 335-356

\section{REGIONALNI RAZVOJ MALOPRODAJE U SRBIJI - NEDOSTATAK KLJUČNIH INDIKATORA PERFORMANSI I RAZVOJA}

Apstrakt: Glavno istraživačko pitanje postavljeno na početku ovog rada bilo je vezano za utvrđivanje regionalnih razlika u prostornom razvoju trgovine $u$ Srbiji. Cilj rada bio je analiza regionalnih razlika u trgovinskom razvoju a na bazi raspoloživih statističkih podataka. Ideja je bila da se istaknu regioni sa nedovoljno razvijenom trgovinom $i$ oni sa ugroženom trgovinskom konkurencijom. Urađeno je sveobuhvatno kabinetsko istraživanje. Ono je obuhvatilo detaljnu analizu prethodnih istraživanja i raspoloživih statističkih baza podataka. Međutim, nepostojanje podataka o razvijenosti trgovine na nižim nivoima agregacije (lokalnom i regionalnom) onemogućili su autorima da izvedu pouzdanije zaključke. Zbog toga je, u toku samog istraživanja, došlo i do promene osnovnog istraživačkog pitanja, koje sada glasi: adekvatnost podatka u maloprodajnom sektoru i potencijalna rešenja. Utvrđivanje nedostajućih ključnih podataka, kao i mogućih rešenja postali su i glavni cilj rada. Rezultat sprovedenog istraživanja jeste činjenica da donosioci odluka u Srbiji ne raspolažu adekvatnim informacijama o maloprodajnoj mreži. Zbog ovoga nastaju problemi u utvrđivanju nedozvoljenih konkurentskih radnji, kao i u planiranju (stimulisanju) maloprodajne mreže, bilo da je reč o javnom ili privatnom sektoru. Popis maloprodajne mreže pomogao bi u definisanju ključnih indikatora maloprodajnog razvoja po regionima i opštinama. Međutim, predložena rešenja moraju biti održiva, što zahteva promene određenih pravnih rešenja kako bi se vršilo kontinuirano ažuriranje jednom prikupljene popisom baze podataka.

Ključne reči: maloprodaja, regionalni razvoj, informaciona baza, konkurencija, Srbija, maloprodajna mreža 


\section{Authors' biographies}

Dragan Stojković, PhD, is an Associate Professor at the Faculty Economics, University of Belgrade. He teaches undergraduate courses in Marketing Channels, Trade Management, Trade Marketing and Sales Management as well as a graduate courses in E-commerce and Internet Marketing.He has received his MBA in marketing from Hofstra University, USA. Both $\mathrm{PhD}$ and Bachelor's degree in economics, he received from the University of Belgrade. He participated in over 100 consulting projects for leading domestic and international clients. These were projects in the field of marketing, management, e-commerce, marketing channels, as well as macroeconomic projects for the Government and its institutions. He has published significant number of scientific papers in domestic and international publications.

Emilija Manić, $\mathrm{PhD}$, graduated in 2000 from the Faculty of Geography, University of Belgrade where she obtained her $\mathrm{PhD}$ degree in 2008. During the 2001-2013 period, she worked as an Assistant Professor at the Faculty of Economics, University of Belgrade and was appointed an Associate Professor in 2014 at the same institution. She conducted international scientific research and has experience in the location and spatial analysis, environmental and socioeconomic background analysis and regional development. She participated in several international and many domestic research projects as a team expert within interdisciplinary research teams. Her recent assignments include participation in the on-going H2020 project as a team member Environmental Expert, and in WB project as Social Development Specialist.

Zoran Bogetić, $\mathrm{PhD}$, is a Full Professor at the Faculty of Economics, University of Belgrade. He received his Ph.D. in 2006 at the Faculty of Economics, where he has been employed since 1991. He was elected as a full professor in 2016. Research and teaching preoccupation includes the following areas: retail, marketing channels, product category management, key customer management and purchasing marketing. He is also the author of a number of books and expert articles in the fields of research focus. In basic studies he teaches courses in Marketing Channels, Trade Management and Trade Marketing and Sales Management. He is also engaged in master program, as well as doctoral studies. He is a member of the Serbian Association for Marketing and the Scientific Society of Economists of Serbia.He has also conducted numerous inhouse training programs in the field of trade marketing and management and creative partnership initiatives in marketing channels.

Aleksa Dokić, M.Sc, is a Teaching Associate at the Faculty of Economics, University of Belgrade. He finished his bachelor studies in 2015, after which he continued his education at Technical University in Munich (TUM). In 2017, he finished the eminent UN official M.Sc. program in Sustainable Resource Management at TUM. In 2016 he also enrolled in the master program Trade - Sales and Supply Chain Management at the Faculty of Economics in Belgrade, where he is currently pursuing his second degree. On bachelor studies, he is currently teaching the courses in Marketing Channels, Trade Management, and Trade Marketing and Sales Management. Alongside the aforementioned, he has also participated in many projects, in the field of marketing, corporate management, marketing channels, as well as projects for the Government. 